\title{
高波による浸水の想定手法
}

\section{A Method to Predict Flooding Caused by High Waves}

\author{
加藤史訓 $^{1} \cdot$ 諏訪義雄 $^{2} \cdot$ 殿最浩司 $^{3} \cdot$ 真期俊行 $^{4} \cdot$ 志方建仁 $^{5}$ \\ Fuminori KATO, Yoshio SUWA, Koji TONOMO, Toshiyuki MAKI and Takemi SHIKATA
}

\begin{abstract}
The purpose of this study is to establish a method to predict flooding caused by high waves. The method includes an estimation of the highest waves and storm surges generated by a depression and a typhoon, a numerical simulation on flooding caused by wave overtopping, and an effective output of the flood expectation. The method was examined through a case study on the flooding in the Shimonikawa Coast in February 2008 by considering short-term wave overtopping rates.
\end{abstract}

\section{1.はじめに}

2008 年 2 月の富山湾での高波災害のように, 避難が必 要になるような越波が生じる恐れがある地域では, 適切 な避難を促すため高波による浸水を事前に想定する必要 がある．関係省庁が発行した津波・高潮ハザードマップ マニュアル（以下，「マニュアル」という）では, 高潮 による浸水の想定手法がまとめられているが, 高波が浸 水の原因となる場合における波浪の想定方法など, 高波 災害特有の危険性を想定する上で不足している点があ る.そこで, 高波による浸水想定の手順を整理し, 2008 年 2 月の高波で浸水被害が生じた下新川海岸を対象とし たケーススタディにより, その妥当性について検討した。

\section{2. 浸水想定の手順}

始めに，高波による浸水想定の手順を図-1のように整 理した. 浸水想定においては, 資料の収集・整理により, 対象とする台風や低気圧などの外力条件を設定するとと もに, 海底や陸上の地形デー夕を作成する. 次に, 過去 の顕著な高波事例を対象に波浪や高潮の再現計算を行 い, モデルの再現性を確認する。 そして, 再現性が確認 されたモデルを用いて, 想定最大規模の波浪や高潮を子 測し，それによる浸水想定の結果を表示する.

外力条件の設定においては, 最悪の浸水状況を想定す るため, 想定される最大規模の台風および低気圧により 引き起こされる波浪および潮位偏差を算定する必要があ る. 台風による想定最大規模の波浪等は, マニュアルに

\begin{tabular}{|c|c|c|}
\hline 1 正会員 & 工修 & $\begin{array}{l}\text { 国土交通省国土技術政策総合研究所 } \\
\text { 河川研究部海岸研究室 主任研究官 }\end{array}$ \\
\hline 2 正会員 & & $\begin{array}{l}\text { 国土交通省国土技術政策総合研究所 } \\
\text { 河川研究部 海岸研究室長 }\end{array}$ \\
\hline 3 正会員 & 博 (工) & (株) ニュージェック港湾・海岸グループ \\
\hline 4 & & (株) ニュージェック港湾・海岸グループ \\
\hline 5 & 工修 & (株) ニュージェック港湾・海岸グループ \\
\hline
\end{tabular}

従って, 既往最大規模（あるいは想定最大規模）の台風 が最悪の経路（波高や潮位偏差が最大となる経路）を移 動することを仮定して算定できる，一方，低気圧につい ては, 周辺の気圧分布の影響も受けた風の場によって波 浪が決定されることから, 台風と同様に取り扱うことが できない.一つの方法として, 対象海岸で既往最大波高 が観測された時の低気圧による強風が長時間継続するも のと仮定して，想定最大規模の波浪および高潮を推算す る方法が考えられる.

浸水計算では, 越波流量を境界条件とする平面二次元 不定流モデルを使用できるが, 実際の越波は平均越波流 量で表されるような平均的なものではなく, 波群等によ り間欠的に生じている。 そこで, シングルサーメーショ ン法（高山ら，1989）で不規則波の水位変動を算定し, それを基に堰の越流公式を準用する方法（平石ら，1996） により越流量の時系列変化（短時間越波流量）を算定し,

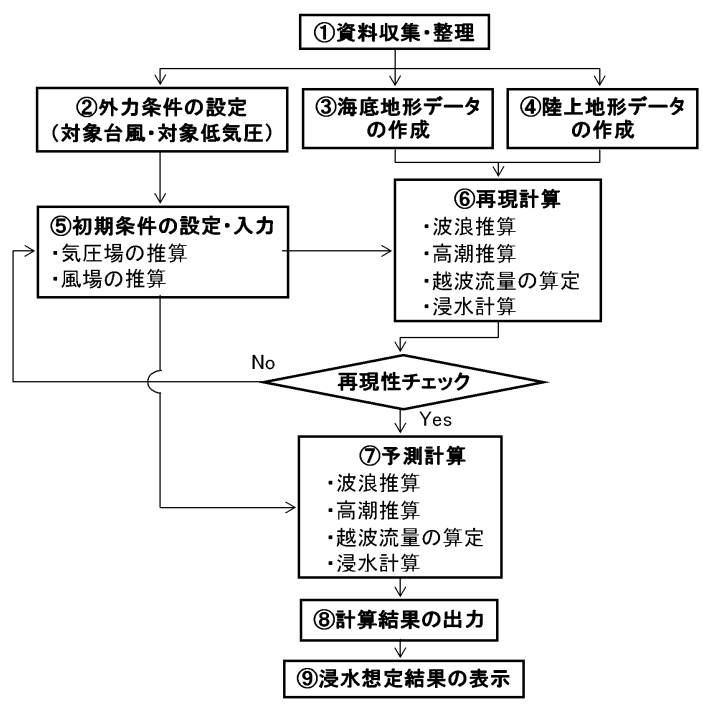

図-1 高波浸水想定の手順 
それを浸水計算に用いることが考えられる．また，排水 工等により越波で流入した海水の排水が見达める場合に は，その効果を考慮して浸水計算を行う。

浸水想定結果の表示では, 高潮による浸水と比べて動 的な水理現象の危険性を, 住民が自分の問題として認識 できるようにする必要がある，その方法として，最大浸 水深の平面分布だけでなく，浸水深の時間的変化をアニ メーションで表示したり，特に高波の発生頻度が低い海 岸では，想定される高波による越波や浸水の様子を見慣 れた風景の写真に合成することなどが考えられる。また， 浸水想定結果の周知には，ハザードマップの作成だけで なく，ハザードマップの作成段階からワークショップな どを通じて、危険性について住民とコミュニケーション を図る必要がある。

なお，浸水想定結果を住民等に説明する上で，想定さ れる浸水がどの頻度の確率で生じるのか把握しておく必 要がある．越波には波高とともに周期が影響することか ら，波高の生起確率だけでなく，関本ら（1999）の方法 で波高と周期の結合生起確率を評価することが考えられる.

\section{3. ケーススタディ}

\section{（1）対象海岸}

図-2に示す富山県下新川海岸を対象に，ケーススタデ イを行った。この海岸は黒部川河口周辺に位置しており， 1970年2月など，寄り回り波によってたびたび災害が発 生している。2008年2月24日には，この海岸に設置され ている田中観測所（水深 $12.8 \mathrm{~m}$ ）に押いて波高 $6.62 \mathrm{~m}$ ，周 期13.9秒が観測され，越波による浸水や海岸堤防等の被 災が生じている。

\section{（2）既往の高波の推算}

田中観測所で高波浪が観測された擾乱と，寄り回り波 などの高波が生じたと言われている擾乱を対象に，波浪 推算を行った。対象啰乱を表-1に示す。

風の場の算出には, 台風近傍では台風モデル（Myers の式）を，台風影響範囲よりも遠方の地点や低気圧によ る高波については傾度風モデルを適用した。算出された 風の場を用いて，想定最大規模の波浪をSWANで推算し た. 地形デー夕は，日本近海についてはJTOPO30などを， 下新川海岸近傍ではナローマルチビームで取得された高 精度の測量成果を使用した。波浪推算では，日本近海 $\left(\mathrm{N} 20-55^{\circ}, \mathrm{E} 120-170^{\circ}\right)$ から下新川海岸近傍まで7領域を 設定し，計算格子間隔も各領域の大きさに応じて $36 \mathrm{~km}$ から $50 \mathrm{~m}$ まで徐々に小さく設定した。

表-1のように，各擾乱の推算值は観測值と概ね一致し て抢り，推算波高はL700201が最大で， $8.29 \mathrm{~m}$ と推算さ れている．近藤ら（1985）はL700201による輪島の波高 を $10.14 \mathrm{~m}$ と推算しているが，今回使用したモデルによる

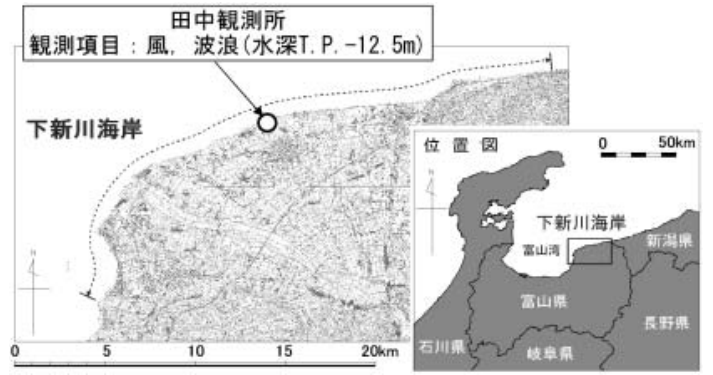

図-2 ケーススタディの対象海岸の位置

表-1 波浪推算を行った擾乱と田中観測所での観測值・推算值

\begin{tabular}{|c|c|c|c|c|c|c|}
\hline \multirow{2}{*}{$\begin{array}{l}\text { 挸 } \\
\text { 乱 }\end{array}$} & \multirow{2}{*}{ ケース名 } & \multirow{2}{*}{ 起時 } & \multicolumn{2}{|c|}{ 観測值 } & \multicolumn{2}{|c|}{ 推算値 } \\
\hline & & & $\mathrm{H}_{1 / 3}(\mathrm{~m})$ & $\mathrm{T}_{1 / 3}(\mathrm{~s})$ & $\mathrm{H}_{1 / 3}(\mathrm{~m})$ & $\mathrm{T}_{1 / 3}(\mathrm{~s})$ \\
\hline \multirow{5}{*}{$\begin{array}{l}\text { 低 } \\
\text { 気 } \\
\text { 圧 }\end{array}$} & L080224 & 2008.2 .24 & 6.62 & 13.9 & 6.51 & 14.3 \\
\hline & L031220 & 2003.12 .20 & 5.23 & 12.0 & 6.01 & 13.6 \\
\hline & L910216 & 1991.2 .16 & 欠測 & 欠測 & 6.35 & 12.1 \\
\hline & L881029 & 1988.10 .29 & 5.82 & 11.4 & 4.11 & 10.5 \\
\hline & L700201 & 1970.2 .1 & \multicolumn{2}{|c|}{ 観測開始前 } & 8.29 & 14.1 \\
\hline \multirow{3}{*}{ 台 } & T0423 & 2004.10 .21 & 4.46 & 8.9 & 4.44 & 10.3 \\
\hline & Т9019 & 1990.9 .20 & 5.85 & 11.0 & 5.81 & 11.7 \\
\hline & T5915 & 1959.9 .26 & \multicolumn{2}{|c|}{ 観測開始前 } & 3.82 & 8.5 \\
\hline
\end{tabular}

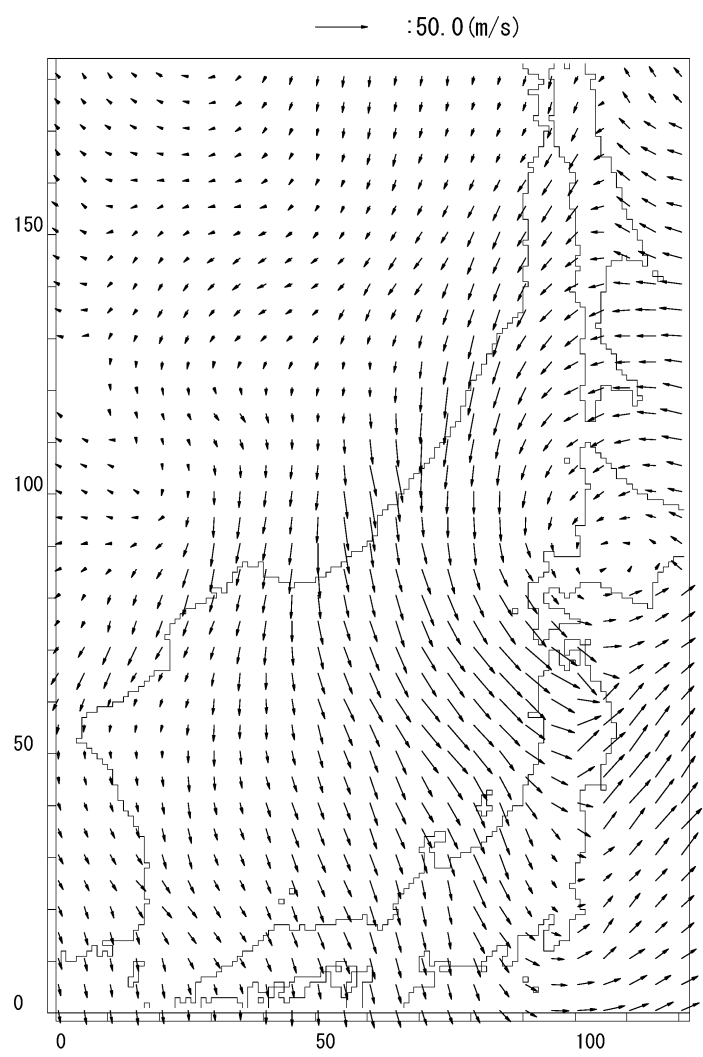

図-3 推算された風速分布（1970年 2 月 1 日 3 時） 
輪島での波高（10.05m）はそれとほぼ一致している.

この推算により，L080224をはるかに上回る高波が過 去に発生していたことが明らかになった。

\section{（3）想定最大波浪の推算}

低気圧による想定最大波浪は, 寄り回り波で大きな被 害が生じたL700201が波高ピーク時（図-3）から停滞す るものとして推算した. 一方, 台風による想定最大波浪は, 富山湾上を通過した台風で最も勢力の強かった伊勢湾台 風（T5915）の経路を図-4のように平行移動（T5915a： 東へ $400 \mathrm{~km}, \mathrm{~T} 5915 \mathrm{~b}$ : 東へ $200 \mathrm{~km}, \mathrm{~T} 5915 \mathrm{c}$ ：移動なし, T5915d：西へ 100km）させるとともに，想定最大規模と して上陸時気圧が $900 \mathrm{hPa}$ となるように気圧を定量低減さ せて推算した。

想定最大波浪の推算結果を表-2に示す。低気圧による 想定最大波浪（L700201a）は，波高，周期とも，L700201 をわずかに上回った。このことは，L700201の高波は， その低気圧規模で発達する最大規模の波浪であったこと を示している，一方，台風による想定最大波浪について は，いずれの経路も $\mathrm{T} 5915$ より波高，周期とも大きくな っていることから，中心気圧低下の効果が大きく現れて いる。また，T5915aやT5915bのように台風経路を対象

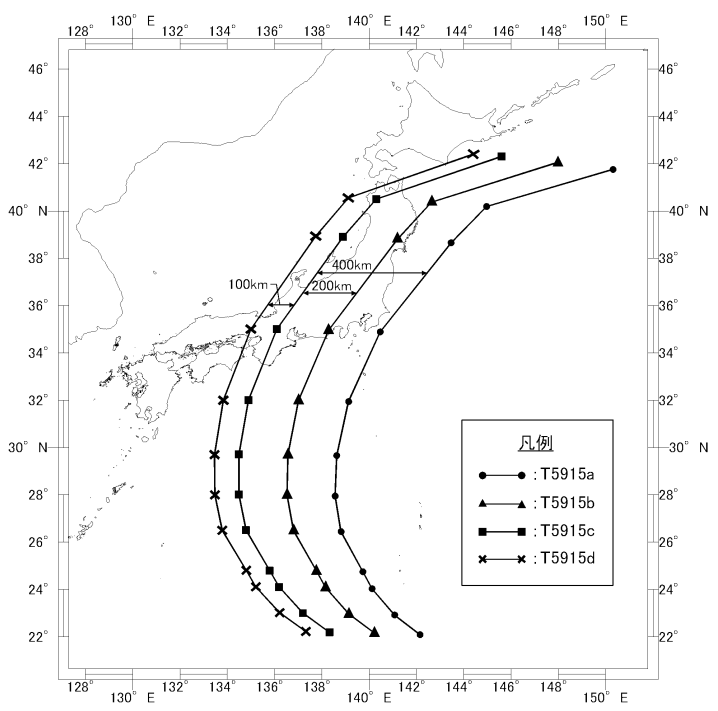

図-4 モデル台風の経路

表-2 想定最大波浪の推算結果

\begin{tabular}{c|c|c|c}
\hline \multirow{2}{*}{ 擾乱 } & \multirow{2}{*}{ ケース名 } & \multicolumn{2}{|c}{ 推算值 } \\
\cline { 3 - 4 } & & $\mathrm{H}_{1 / 3}(\mathrm{~m})$ & $\mathrm{T}_{1 / 3}(\mathrm{~s})$ \\
\hline 低気圧 & L070201a & 8.47 & 14.6 \\
\hline \multirow{4}{*}{ 台風 } & $\mathrm{T} 5915 \mathrm{a}$ & 6.80 & 12.2 \\
\cline { 2 - 4 } & $\mathrm{T} 5915 \mathrm{~b}$ & 6.20 & 11.9 \\
\cline { 2 - 4 } & $\mathrm{T} 5915 \mathrm{c}$ & 5.91 & 10.6 \\
\cline { 2 - 4 } & $\mathrm{T} 5915 \mathrm{~d}$ & 4.28 & 9.2 \\
\hline
\end{tabular}

地点より東に移動することにより, 台風西側での風が大 きくなり, T5915と比べて著しく波高や周期が増大して いる.

\section{（4）波高・周期の結合生起確率}

田中観測所で30年間（1979～2008年）に得られた波浪 データから年最大值統計と極大值統計を整理し, 波高の 極值統計解析および波高・周期の結合生起確率の算定を 行った。 2008年2月の高波の波高は，年最大值統計で約 50 年確率，極大值統計で約 40 年確率と評価された。また, 波高・周期の結合生起確率の分布に台風打よび低気圧に よる想定波浪の波高・周期をプロットしたものが図-5〜 6である１970年2月の高波（L700201）の結合生起確率 は, 年最大值統計で約 $1 / 10,000$, 極大值統計で約 $1 / 3,000$ と算定された。また，想定最大規模の高波（L700201a） の結合生起確率は, 年最大值統計で約 $1 / 12,500$, 極大值 統計で約 1/5,000 となった。これに対し，2008年2月の高 波（L080224）の結合生起確率は, 年最大值統計, 極大 值統計とも約 $1 / 700$ と算定された。

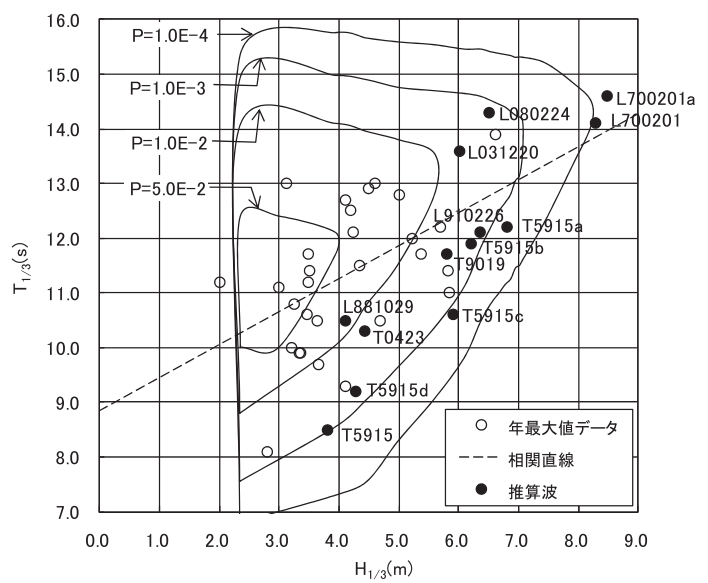

図-5 波高と周期の結合生起確率（田中観測所，年最大值統計）

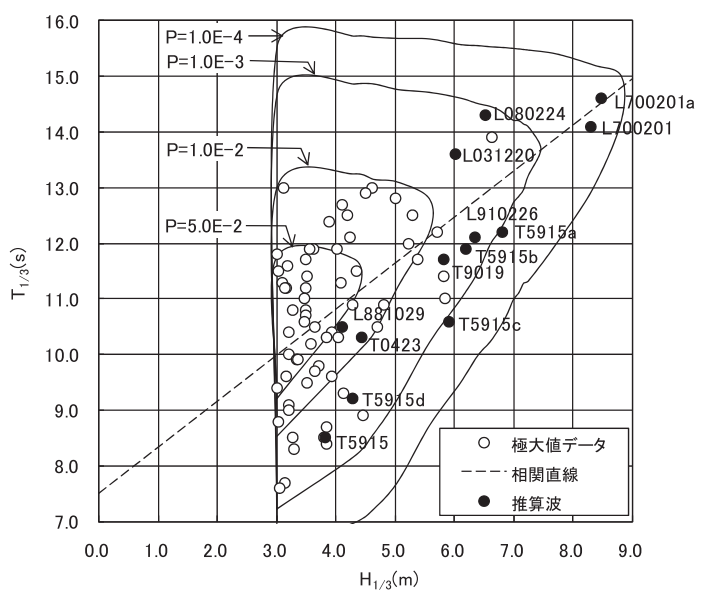

図-6 波高と周期の結合生起確率（田中観測所，極大値統計） 


\section{（5）浸水想定}

L080224で浸水が生じた下新川海岸生地地区（東西 $8 \mathrm{~km}$ ，南北 $13.5 \mathrm{~km}$ ，計算格子間隔 $10 \mathrm{~m}$ ）を対象に，二次 元不定流モデルにより浸水状況の再現計算を行った。こ の地区では，生地鼻を境として，北側は消波工を有する 直立堤，南側は緩傾斜堤となっており，浸水状況から直 立堤で延長 $350 \mathrm{~m}$ (A区間)，緩傾斜堤で延長 $150 \mathrm{~m}$ （B区 間）において越波が生じていたと仮定した。また，全体 的には標高が内陸方向に低くなっており，越波で流入し た海水が堤内地で広がりやすい地形になっている。

再現計算では，2008年2月 24日4〜14時について，生 地沖（水深 $50 \mathrm{~m}$ 地点）の波浪を推算し，その結果を用い て各区間の平均越波流量と短時間越波流量を算定した。 平均越波流量の最大值は $\mathrm{A}$ 区間で $0.0153 \mathrm{~m}^{3} / \mathrm{m} / \mathrm{s}, \mathrm{B}$ 区間で $0.0234 \mathrm{~m}^{3} / \mathrm{m} / \mathrm{s}$ となった。短時間越波流量は，シングルサ ーメーション法により図-7のように算定され，瞬間的に は $5 \mathrm{~m}^{3} / \mathrm{m} / \mathrm{s}$ 以上の越波が生じている。なお，越波流量計 算における潮位は，生地観測所における2月24日の最高 潮位（T.P. + 0.31m）とした。

この海岸堤防には排水工が設けられているものの，そ の排水能力は定かではないが，越波流量から $0.01 \mathrm{~m}^{3} / \mathrm{m} / \mathrm{s}$ を差し引くことで実際の浸水域をほぼ再現できたことか ら，この方法で最大浸水深や最大流速を算定した。堤内 地においては，この地区の東側にある河川での自然排水 のみを浸水計算で考慮している.

図-8は，浸水の再現計算で得られた最大浸水深と最大 流速の平面分布である. 最大浸水深の計算結果を見ると，

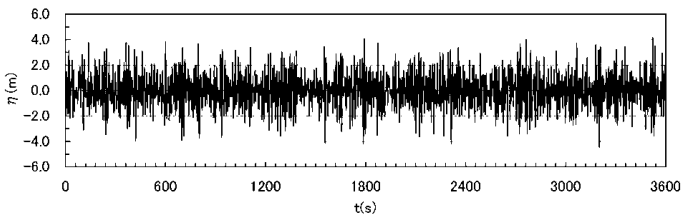

（1）生地沖の水位の時系列変化

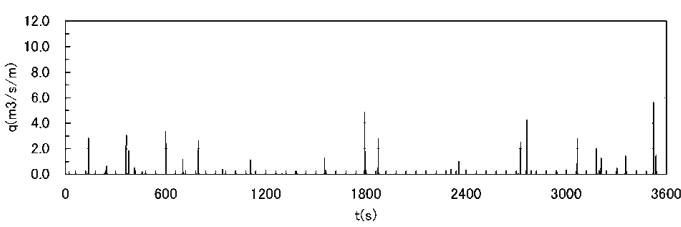

（2） $\mathrm{A}$ 区間 $\sigma$ 越波流量の時系列変化

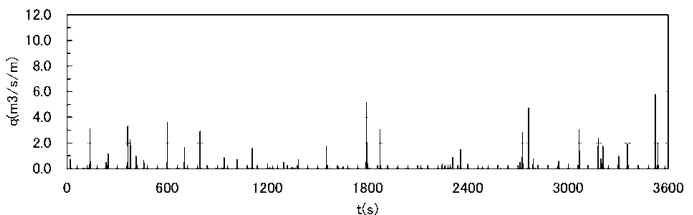

（3） B 区間の越波流量の時系列変化

図-7 2008年2月高波（L080224）による短時間越波流量（波 高ピーク時)
計算で得られた浸水域は実際の浸水域（図中に線で表示） より広がっているが，浸水深 $0.2 \mathrm{~m}$ 以上の領域は実際の浸 水域とほぼ一致している。これは, 越波が長時間継続し ている中で，土のう積みなどの水防対応や，側溝などに よる浸水域での排水を計算では見达んでいないためと考 えられる。また，境界条件が平均越波流量でも短時間越 波流量でも浸水域はほぼ同様である。一方，最大流速に ついては，平均越波流量を用いた場合にはほとんどが $0.4 \mathrm{~m} / \mathrm{s}$ 以下となっているが，短時間越波流量を用いた場 合には $1.6 \mathrm{~m} / \mathrm{s}$ 以上となっている箇所がある。最大浸水深 や最大流速の空間最大值は，平均越波流量を用いた場合 には $1.4 \mathrm{~m}$ と $1.0 \mathrm{~m} / \mathrm{s}$ ，短時間越波流量を用いた場合には $1.9 \mathrm{~m}$ と $2.7 \mathrm{~m} / \mathrm{s}$ となった。

近隣の入善町芦崎地区において越波で流入した海水が 津波のように道路を流れる様子が報道されていることか ら判断すると, 流速 $0.4 \mathrm{~m} / \mathrm{s}$ は明らかに過小と考えられる. このように，短時間越波流量を境界条件とした浸水計算 により，実態に近い浸水状況が再現できることが示さ れた。
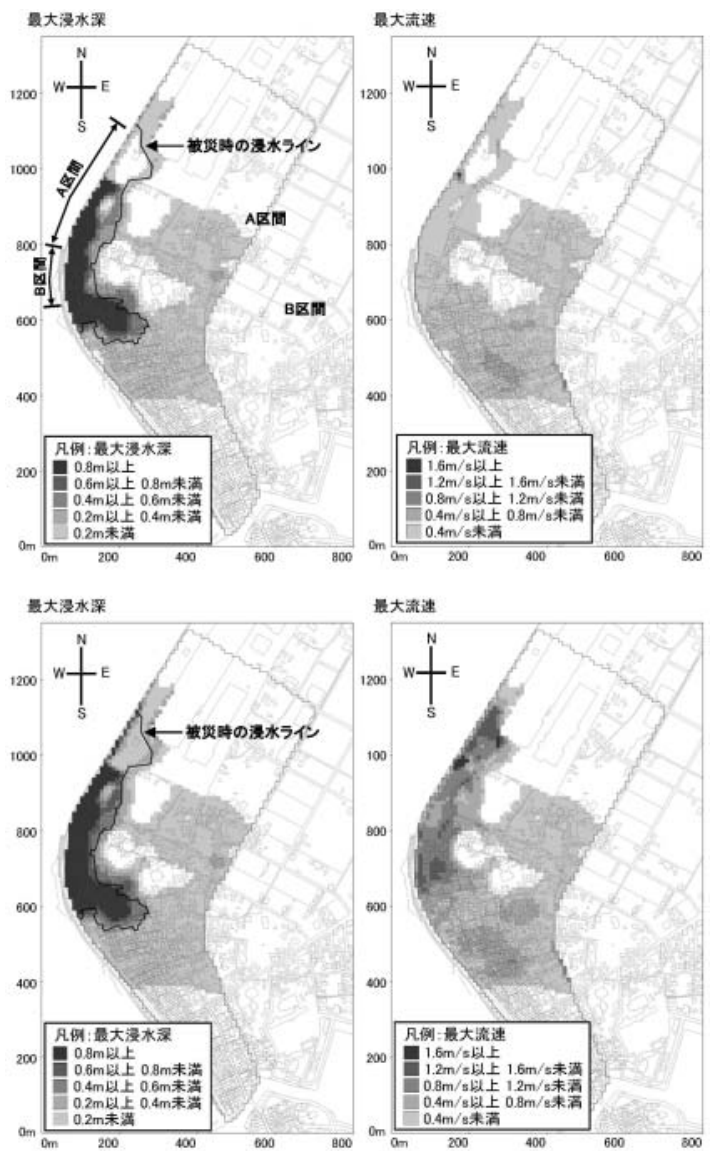

図-8２008年2月高波（L080224）による最大浸水深，最大流速 (上：平均越波流量，下：短時間越波流量） 
次に, 想定最大波浪 (L700201a) による浸水の想定計 算を，L080224 と同様に排水能力を考慮して行った。想 定最大波浪は強風が長時間継続すると仮定して推算され たものであるが, 浸水計算では波高がほぼピークに達し た時刻で計算を打ち切った。な扔，柴木ら（2002）にな らい radiation応力を考慮した高潮推算を行った結果, 最 大潮位偏差は $0.16 \mathrm{~m}$ と推算されたことから, これを朔望 平均満潮位に上乗せしたT.P. $+0.63 \mathrm{~m}$ で越波流量を計算 した.

この波浪では, 平均越波流量の最大值は, $\mathrm{A}$ 区間で $0.0461 \mathrm{~m}^{3} / \mathrm{m} / \mathrm{s}$, B 区間で $0.1071 \mathrm{~m}^{3} / \mathrm{m} / \mathrm{s}$ となり，L080224の3 倍以上に増加している。 また, 両区間とも, 短時間越波 流量が $10 \mathrm{~m} / \mathrm{m} / \mathrm{s}$ 以上となることがあった．図-9のように, 平均越波流量, 短時間越波流量とも, L080224より, 浸
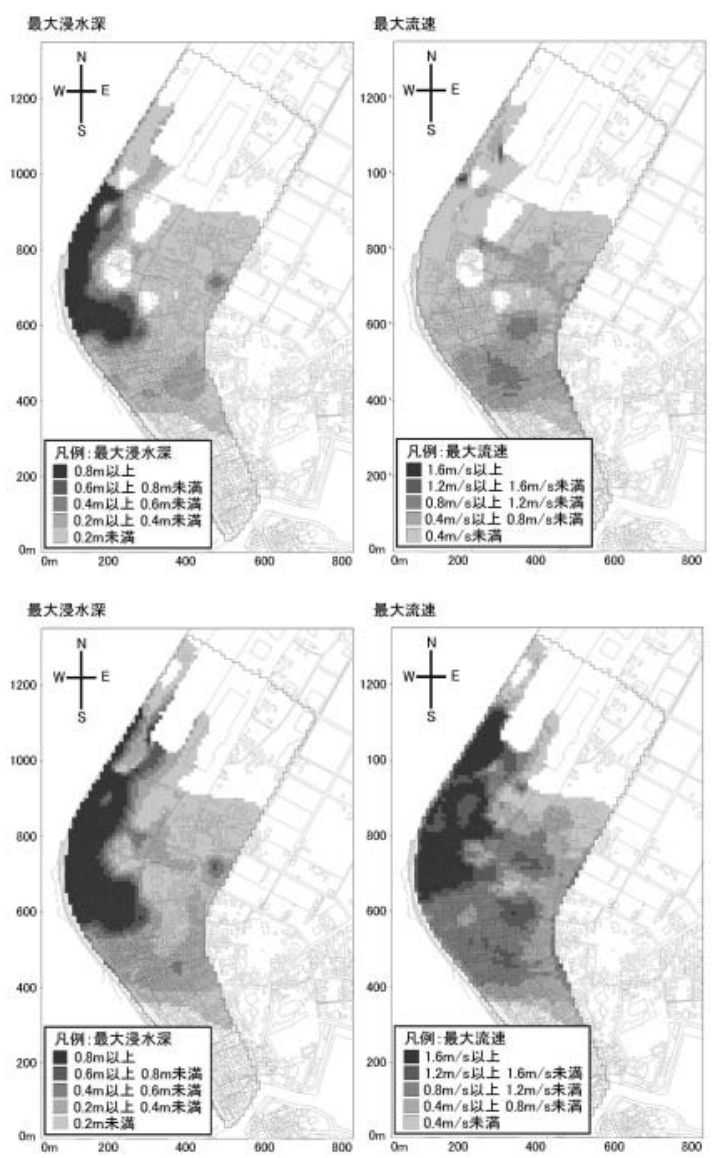

図-9 想定最大波浪（L700201a）による最大浸水深, 最大流速 (上：平均越波流量, 下：短時間越波流量)
水域が広がり, 最大流速が大きくなっている. 最大浸水 深や最大流速の空間最大值は, 平均越波流量を用いた場 合には $1.6 \mathrm{~m}$ と $1.6 \mathrm{~m} / \mathrm{s}$, 短時間越波流量を用いた場合には $3.6 \mathrm{~m}$ と $3.6 \mathrm{~m} / \mathrm{s}$ となった。

\section{4. おわりに}

本研究で得られた主な結論は以下のと抢りである.

・高波による浸水の想定手順を整理し, 下新川海岸での ケーススタディでその適用性を確かめた。

・低気圧および台風による想定最大波浪の推算を試み, それによる浸水の発生頻度を説明する観点から, その波 高と周期の結合生起確率を評価した.

・ 排水能力を考慮した浸水計算に押いて短時間越波流量 を使用することで，下新川海岸生地地区での 2008 年 2 月 の越波による浸水状況を再現できた。 また，そのモデル を用いて, 想定最大波浪の越波による浸水想定計算を行 うことができた。

謝辞：北陸地方整備局黒部河川事務所からは海底地形デ ー夕および海象と浸水に関するデー夕を, 黒部市都市建 設部都市計画課より陸上地形デー夕を提供していただい た。また, 波高・周期の結合生起確率の計算方法につい て, 五洋建設 (株) 技術研究所の関本恒浩博士にご教示 いただいた。ここに記して謝意を表します。

\section{参 考 文 献}

近藤浩右・鈴木義和・鹿島遼一・土屋義人 (1985)：日本海中 部沿岸に抢ける沿岸波浪の極值統計と佐渡島遮蔽域の波 浪特性，海岸工学論文集，No. 32，pp. 129-133.

関本恒浩・花山格章 - 片山裕之・清水玩三（1999）：設計波周 期の設定方法の提案, 海岸工学論文集, No. 46, pp. 256260.

柴木秀之・渡辺 晃 (2002)：密度成層とWave Setupを考虑し た多層高潮推算に関する研究, 土木学会論文集, No. 719, II-61, pp. 47-65.

高山知司・平石哲也・立石義博（1989）：多方向不規則波の造 波信号発生法に関する検討, 海岸工学論文集, No. 36, pp. 153-157.

内閣府 (防災担当) - 農林水産省農村振興局 - 農林水産省水産 庁・国土交通省河川局・国土交通省港湾局（2004）：津 波・高潮ハザードマップマニュアル，128p.

平石哲也 - 望月德雄 - 佐藤一央 - 丸山晴広 - 金澤 剛 - 桝本 達也（1996）：護岸越波流量に打ける波の多方向性の影響, 港湾技術研究所報告, No. 35, Vol. 1, pp. 39-64.

Booij, N., L. H. Holthuijsen and R. C. Ris (1996): The SWAN wave model for shallow water, Proceedings of 25 th International Conference on Coastal Engineering, Vol. 1, pp. 668-676. 